\title{
Analysis of differences in postural stability in people with adult scoliosis and non specific low back pain
}

\author{
L Bissolotti ${ }^{1,3^{*}}$, V Sani ${ }^{1,3}$, M Gobbo ${ }^{2,3}$, C Orizio $^{2,3}$ \\ From 9th International Conference on Conservative Management of Spinal Deformities - SOSORT 2012 \\ Annual Meeting \\ Milan, Italy. 10-12 May 2012
}

\section{Background}

Few papers demonstrated an impairment in postural stability control in patients with non specific low back pain (NL) $[1,2]$. However, it is not clear whether patients with adult scoliosis (AS) and NL can be considered a specific subgroup.

\section{Aim}

Present a study aimed to compare Postural Stability (PS) in patients with AS and NL[3].

\section{Methods}

Cotrel method was used to assess Cobb angle (CA) on plan $\mathrm{x}$-ray. Using 14 markers, a two optoelectronic infrared cameras (Gemini, BTS spa, Milano, Italy) was used to perform a stabilometric test when patients were keeping a quite standing position with an eyes open trial (EOT), and eyes closed (ECT), and a distance between their feet (FD) as preferred. The Area of Reference Marker on the Ground (C7) (ARMG), Average Marker Speed (AMS) and length of the marker's trajectory on the ground (LMG) were evaluated during ST.

\section{Results}

AS-Group included 40 patients, 10 men and 30 women, with Cobb angle $>15^{\circ}$, mean age $61.8 \pm 11.5$ years, BMI $23.6 \pm 2.8 \mathrm{~kg} / \mathrm{m} 2$. A single curve was present in 32 patients (80\%). Cobb angle of primary curve averaged 27.1 $\pm 11.5^{\circ}$ (range, $15-63^{\circ}$ ), thoracic Cobb angle averaged $25.5 \pm 22.3^{\circ}$ (range, $8-58^{\circ}$ ). NL-Group included 40 patients, 9 men and 31 women. Mean age $58.2 \pm 10.9$ years, BMI

${ }^{1}$ Servizio di Recupero e Rieducazione Funzionale, Casa di Cura Domus Salutis, Brescia, Italy

Full list of author information is available at the end of the article
$23.9 \pm 3.2 \mathrm{~kg} / \mathrm{m} 2$. In AS-group, the self selected mean FD during EOT was $160.1 \pm 53.8 \mathrm{~mm}$, and during ECT it averaged $160.9 \pm 56.2 \mathrm{~mm}(\mathrm{p}>0.05)$. In NL group it was 157.5 $\pm 53.1 \mathrm{~mm}$ during EOT, and $154.6 \pm 51.2 \mathrm{~mm}$ during ECT $(p>0.05)$. No differences were noted in both conditions between the two groups ( $p>0.05)$. In AS-group, ARMG values averaged $302.6 \pm 271.6 \mathrm{~mm} 2$ during EOT, and $577.9 \pm 728.9 \mathrm{~mm} 2$ during ECT $(\mathrm{p}>0.05)$. LMG was $156.9 \pm 37.2 \mathrm{~mm}$ during EOT, and $211.5 \pm 72.5 \mathrm{~mm}$ during ECT ( $>0.05)$; while the AMS was respectively $5.3 \pm 1.2 \mathrm{~mm} / \mathrm{sec}$ and $7.1 \pm 2.4 \mathrm{~mm} / \mathrm{sec}(\mathrm{p}>0.05)$. In NL group, ARMG averaged $296.1 \pm 387.6 \mathrm{~mm} 2$ during EOT, and $876.1 \pm 1347.8 \mathrm{~mm} 2$ during ECT ( $>0.05)$. LMG was respectively $176.1 \pm 62.2 \mathrm{~mm}$ and $246.1 \pm 183.5 \mathrm{~mm}$ ( $>>0.05)$; while AMS has been $5.5 \pm 1.9 \mathrm{~mm} / \mathrm{sec}$ and $9.9 \pm 9.5 \mathrm{~mm} / \mathrm{sec}$ ( $p>0.05$ ). Romberg Coefficient (RC) was $2.3 \pm 1.9$ in AS group and $2.9 \pm 2.6$ in NL group ( $\mathrm{p}>0.05)$.

\section{Conclusions}

In AS-Group, the ability to control PS with EO and EC was not different than in NL-Group. Physiotherapy program does not require more attention to PS training in AS-Group than NL-Group.

\footnotetext{
Author details

${ }^{1}$ Servizio di Recupero e Rieducazione Funzionale, Casa di Cura Domus Salutis, Brescia, Italy. ${ }^{2}$ Istituto di Fisiologia Umana, Dipartimento di Scienze Mediche e Biotecnologie, Facoltà di Medicina e Chirurgia, Brescia, Italy. 'LARIN: Laboratorio di Ricerca Neuromuscolare e dell'Attività Fisica Adattata, Italy.

Published: 3 June 2013

\section{References}

1. Ruhe A, Fejer R, Walker B: Center of pressure excursion as a measure of balance performance in patients with non-specific low back pain
} 
compared to healthy controls: a systematic review of the literature. Eur Spine J 20(3):358-368.

2. Brumagne S, Janssens L, Knapen S, Claeys K, Suuden-Johanson E: Persons with recurrent low back pain exhibit a rigid postural control strategy. Eur Spine J 2008, 17(9):1177-1184.

3. Beaulieu M, Toulotte C, Gatto L, Rivard CH, Teasdale N, Simoneau M, Allard P: Postural imbalance in non-treated adolescent idiopathic scoliosis at different periods of progression. Eur Spine J 2009, 18(1):38-44.

doi:10.1186/1748-7161-8-S1-P3

Cite this article as: Bissolotti et al: Analysis of differences in postural stability in people with adult scoliosis and non specific low back pain. Scoliosis 2013 8(Suppl 1):P3.

Submit your next manuscript to BioMed Central and take full advantage of:

- Convenient online submission

- Thorough peer review

- No space constraints or color figure charges

- Immediate publication on acceptance

- Inclusion in PubMed, CAS, Scopus and Google Scholar

- Research which is freely available for redistribution

Submit your manuscript at www.biomedcentral.com/submit 